University of Nebraska - Lincoln

DigitalCommons@University of Nebraska - Lincoln

Publications from USDA-ARS / UNL Faculty

U.S. Department of Agriculture: Agricultural

Research Service, Lincoln, Nebraska

2003

Normal Acquisition and Loss of Bone Mass

Steven A. Abrams

United States Department of Agriculture-Agricultural Research Service

Follow this and additional works at: https://digitalcommons.unl.edu/usdaarsfacpub

Part of the Agricultural Science Commons

Abrams, Steven A., "Normal Acquisition and Loss of Bone Mass" (2003). Publications from USDA-ARS / UNL Faculty. 644.

https://digitalcommons.unl.edu/usdaarsfacpub/644

This Article is brought to you for free and open access by the U.S. Department of Agriculture: Agricultural Research Service, Lincoln, Nebraska at DigitalCommons@University of Nebraska - Lincoln. It has been accepted for inclusion in Publications from USDA-ARS / UNL Faculty by an authorized administrator of DigitalCommons@University of Nebraska - Lincoln. 


\title{
Normal Acquisition and Loss of Bone Mass'
}

\author{
Steven A. Abrams \\ US Department of Agriculture/Agricultural Research Service, Children's Nutrition Research Center, \\ Department of Pediatrics, Baylor College of Medicine and Texas Children's Hospital, Houston, Tex., USA
}

\section{Key Words}

Calcium absorption - Bone growth • Bone mass • Human milk

\begin{abstract}
The natural patterns of bone mass accumulation and loss with age represent the templates of individual life cycle periods that are distinguished by marked, physiologically and genetically identifiable, changes in bone mass. During the third trimester of pregnancy, maternal calcium absorption increases and the fetus accumulates about two-thirds of the total bone mass of the term infant. In early infancy, human milk calcium is derived primarily from maternal bone stores, which incur substantial bone losses that are quickly replenished during and after weaning. At puberty, a marked increase in bone mass occurs in conjunction with the initial physical and hormonal changes that characterize this stage. Calcium absorption and bone calcium deposition rates peak in females shortly before menarche. At that time, the bone

This work is a publication of the US Department of Agriculture (USDA)/ Agricultural Research Service (ARS), Children's Nutrition Research Center, Department of Pediatrics, Baylor College of Medicine and Texas Children's Hospital, Houston, Tex. This project has been funded in part with federal funds from the USDA/ARS under Cooperative Agreement number 58-6250-6-001. The contents of this publication do not necessarily reflect the views or policies of the USDA, nor does mention of trade names, commercial products or organizations imply endorsement by the US Government.
\end{abstract}

\section{KARGER}

Fax +4161306 1234

E-Mail karger@karger.ch

www.karger.com (c) 2003 S. Karger AG, Basel

Accessible online at: www. karger.com/hre calcium deposition rate is approximately five times that of adulthood. Skeletal bone mass reaches over $90 \%$ of its maximum by age 18 (earlier in females) but does not peak until age 25-30. At some point in mid-life, women experience perimenopause, the 3- to 5-year period prior to menopause during which estrogen levels begin to drop and there are marked increases in bone resorption and loss. Throughout adulthood, calcium absorption efficiency from the diet gradually declines.

Copyright $@ 2003$ S. Karger AG, Basel

\section{Lifetime Patterns of Bone Accumulation}

The development of bone mass during infancy and childhood and the loss of bone mass in later life are chronicled in a considerable amount of available data. The majority of the older data were derived from measurement of whole body or regional bone mass using some form of densitometric equipment, while more recent studies utilize the contemporary technology of dual-energy Xray absorptiometry (DEXA) to assess populations based on age, gender or ethnicity. In this article, I will describe the role of calcium in establishing bone mass during childhood and adolescence and will outline the life cycle changes in calcium requirements and utilization that occur in healthy children, adolescents and adults.

Calcium balance data suggest that, in general terms, calcium is a threshold nutrient. This indicates that in- 
takes, as established for any given life stage and gender, below an optimal level are unlikely to lead to maximal calcification of the skeleton [1]. Similarly, calcium intakes above the threshold will not add appreciably to skeletal retention. Low calcium intakes, especially in conjunction with inadequate exercise and lack of other critical nutrients such as magnesium, phosphorus and zinc, may not lead to maximum genetically determined bone mass. This concept was the basis of the recent revision of dietary guidelines for calcium intake in the United States, shown in table $1[2,3]$.

Available data further suggest that absorption and utilization of calcium for skeletal development are highly dependent on life stage, as well as the existence of disease processes. Fractional absorption of calcium is highest in infancy $(50-60 \%)$, especially when infants are provided

Table 1. Recommended adequate dietary calcium intake levels

\begin{tabular}{lc}
\hline Life stage group & $\begin{array}{l}\text { Calcium AI } \\
\text { mg/daya }\end{array}$ \\
\hline $0-6$ months & 210 \\
7-12 months & 270 \\
1-3 years & 500 \\
4-8 years & 800 \\
9-13 years & 1,300 \\
14-18 years & 1,300 \\
19-30 years & 1,000 \\
\hline
\end{tabular}

a Adequate intake (AI) for infants is based on the human milk-fed infant. Higher calcium intakes are recommended for formulafed infants. These higher intakes are met by all currently marketed formulas in the United States [2, 3].

Table 2. Lifetime patterns of bone calcium deposition $[6,9,11,12]$ with human milk $[4,5]$. These high absorption fractions exist even in premature infants, whose calcium intakes on a body weight basis are typically up to $200 \mathrm{mg} / \mathrm{kg}$ per day [6]. This incredibly high intake contrasts with that of healthy full-term infants, who absorb the same fraction of calcium on intakes of $15-40 \mathrm{mg} / \mathrm{kg}$ per day during the first year of life. By adulthood, calcium absorption is typically about $30 \%$ on diets providing calcium intakes of $1,000 \mathrm{mg} /$ day $(10-20 \mathrm{mg} / \mathrm{kg}$ per day) [7-9].

Calcium kinetic studies confirm these tremendous variations in utilization of calcium during the life cycle (table 2). It is of interest that the amount of calcium deposited in the skeleton of a $2-\mathrm{kg}$ fetus or premature infant is roughly the same as that deposited in an elderly adult. The difference is the minimal bone resorption in the fetus or infant relative to the adult [6, 9-12].

Gender and ethnic distinctions in bone accumulation have been extensively studied and reviewed. Physiologically, male and female patterns of bone growth are parallel, but, during peak bone growth, these patterns are higher in males than in females. Maximum levels of calcium absorption are similar between genders, but pubertal peaks in calcium absorption are likely maintained for much longer periods of time in males than in females [ 10 , $13,14]$.

Calcium absorption in African-American adolescents is greater than in Caucasians or Hispanics [10]. This difference may not be maintained in adulthood. In contrast, lower urinary excretion of calcium appears to be constant in African-Americans relative to Caucasians or Hispanics throughout childhood and adulthood [15, 16]. Relatively few data are available regarding Asians, but calcium absorption at low intakes was relatively high in a group of Chinese adolescents [17]. Much more data are needed, however, to evaluate calcium absorption in different Asian populations, many of which have little dairy product intake.

\begin{tabular}{lcccc}
\hline & $\begin{array}{l}\text { Age } \\
\text { years }\end{array}$ & $\begin{array}{l}\text { Weight } \\
\mathrm{kg}\end{array}$ & $\begin{array}{l}\text { Bone calcium } \\
\text { deposition } \\
\text { mg/kg per day }\end{array}$ & $\begin{array}{l}\text { Bone calcium } \\
\text { deposition } \\
\text { mg/day }\end{array}$ \\
\hline Premature infants & - & 1.3 & 160 & 214 \\
Full-term infants & $<1.0$ & 8 & 90 & 720 \\
Prepubertal girls & 8.3 & 28 & 52 & 1,456 \\
Pubertal girls & 10.2 & 35 & 56 & 1,960 \\
Postpubertal girls & 15.4 & 59 & 21 & 1,240 \\
Adults & $30-60$ & 60 & $5-10$ & $300-600$ \\
\hline
\end{tabular}




\section{Infancy and Early Childhood}

At birth, healthy, full-term infants have approximately $30 \mathrm{~g}$ total body calcium, a figure that triples to about $90 \mathrm{~g}$ by 1 year of age. Most in utero skeletal calcification occurs during the third trimester. Therefore, premature infants are at particular risk for osteopenia and frank rickets. Although human milk is the standard for the calcium intake of full-term infants, human milk does not contain enough calcium or other bone minerals for most premature infants. It is recommended that infants with a birth weight below $2 \mathrm{~kg}$ receive supplemental minerals, often in the form of a multinutrient powder added directly to their mothers' milk [6, 18].

The calcium needs of full-term infants are met by their mothers' milk during the first 6 months of life. Infant formulas contain more calcium than human milk to accommodate the possibility that the calcium in formulas may not be absorbed as well as the calcium in human milk. Infants who receive cow's milk-based formulas can exceed the amount of calcium absorbed and bone mass accumulated by infants fed human milk. However, at present, there are no data to recommend exceeding the amount of bone formed by exclusively breast-fed infants in the first 6 months of life. In fact, some evidence suggests that breast-fed infants may have greater bone mass later in childhood than that of formula-fed infants, although no controlled trials have evaluated this issue [2-5, 19].

Toddlers are at highest risk for nutritional rickets; the incidence peaks from 6 to 24 months of age [20]. Although usually related to inadequate vitamin D status, there is good evidence that, with extremely low calcium intakes (less than about $250 \mathrm{mg} /$ day), toddlers are at risk for rickets despite adequate vitamin D intake. Among the factors currently contributing to nutritional rickets are low-mineral macrobiotic or vegan diets, increased frequency of breast-feeding without vitamin D supplementation, avoidance of dairy products, and inadequate sunshine exposure (the major source of vitamin D) related to urbanization, sunscreens or the habitual wearing of clothing that covers most of the body.

In the United States, several recent series of rickets cases have been reported. These reports have primarily involved breast-fed African-American children [20, 21]. However, not all cases in the United States have involved breast-fed children or those with dark skin color. From an economic perspective, most cases of rickets in the United States do not appear to be primarily related to an inability to afford dairy products or vitamin D supplements but rather to specific genetic, dietary and lifestyle characteristics. However, in some cases involving the economically disadvantaged, a potential contributing factor worth consideration is that the milk given to a child found to have rickets might have been diluted in an attempt to save money. A further possibility pertains to the contemporary consumer trend involving an increasingly widespread preference for products promoted as 'health foods'. Weaning to a health-food milk alternative lacking vitamin D or calcium fortification may result in severely deleterious outcomes with regard to toddlers' nutrition.

\section{Later Childhood and Adolescence}

Few data are available on the calcium requirements of children prior to puberty. Adequate bone mineral accumulation can be achieved in children 4-8 years of age with calcium intake levels of about $800 \mathrm{mg} /$ day. Potential benefits of increasing calcium intake above that level remain less clear than in pubertal children. In a controlled calcium supplementation trial, Johnston and colleagues [22] demonstrated an increase in bone mass when calcium supplements were given to children as young as 6 years of age. Relatively few children this young were studied, however, and the study was not extended for a long duration. In a follow-up of the Johnston study, the difference in bone mass between groups of children who received calcium supplements and those who did not became insignificant after the supplements were stopped [23]. The interpretation of this finding, however, is uncertain, because it is unlikely that the original study had adequate sample size to evaluate this issue after taking into consideration the effects of the loss of the bone-remodeling transient.

Recently, investigators reported the results of a followup study conducted more than 3 years after completion of the original controlled calcium supplementation trial [24]. The initial study randomly assigned girls (mean age 8 years) to calcium-enriched foods (average calcium supplement intake $850 \mathrm{mg} /$ day) or placebo for 48 weeks. Bone mass was measured by DEXA at the beginning and end of the study. The investigators reported a positive effect of calcium supplementation on area bone mineral density, along with an increased mean gain in bone mineral content and bone size, with a trend toward greater progression in standing height. When the girls were re-examined 3.5 years after conclusion of the initial intervention (with pubertal maturation and spontaneous calcium intake taken into consideration), the increase in bone mineral mass and skeletal longitudinal growth was maintained at a 
highly significant level in the calcium-supplemented group compared with the placebo group.

Investigators have extensively studied calcium requirements, bone mineral acquisition and bone turnover during puberty, due to the high rates of bone mass accumulation during this time. Most clinical studies have primarily evaluated girls, because of the greater risk of osteoporosis in women compared with men. However, available data for both girls and boys suggest that it is important to increase calcium intake during early puberty and maintain this intake throughout adolescence. An adequate intake level for calcium of $1,300 \mathrm{mg}$ daily for 9-18 year olds has been set by the National Academy of Sciences [2] and this value supported in a policy statement by the American Academy of Pediatrics [2, 3]. Despite the differences in physiology between genders and among ethnic groups, there are no data to indicate that dietary calcium recommendations should be modified on the basis of those factors.

Tremendous skeletal growth occurs during puberty, although individuals differ in skeletal acquisition rates and the age at which they attain peak bone mass [25]. In females, approximately $90 \%$ of total body bone mineral content is attained by 17 years of age, rising to $99 \%$ by 27 years of age [26]. Different body sites reach peak bone mass at different ages. The hip attains peak bone mass at age 16-18 years of age, while the vertebrae require several additional years $[27,28]$.

Identification of specific genetic polymorphisms associated with bone accumulation and loss may lead to more precise guidelines for mineral intake. We evaluated the relationship between calcium absorption and restriction fragment length polymorphisms of the vitamin D receptor gene in children 7-12 years of age [29]. We found that the Fok 1 polymorphism was positively associated with calcium absorption $(p=0.04)$. Bone mass differences followed the changes in absorption.

Recent data support the possibility that low bone mass may be a contributing factor in some fractures in children and adolescents. Goulding et al. [30] found lower bone mass in girls with distal forearm fractures than in agematched girls without fractures. A lower calcium intake was reported in the 11- to 15-year-old girls with fractures than in the controls.

Wyshak [31] similarly reported that high calcium intakes decreased the risk of bone fractures in adolescents. $\mathrm{He}$ also reported a positive relationship between fractures and cola beverage intake [32]. However, this link does not prove a direct cause-and-effect relationship. There is no direct evidence that any specific factor in carbonated bev- erages, such as phosphorus, leads to bone loss and fractures in adolescents at normal levels of consumption. It remains of concern that excessive intake of carbonated beverages displaces milk and other dairy product intake, which places such an adolescent at risk for calcium deficiency. Further data on the relationship between dietary factors and fractures are needed before clear public policy statements can be made in this regard. However, based on the available data, it is reasonable to conclude that low calcium intakes may be a significant risk factor for fractures in adolescents.

Numerous studies have documented the importance of exercise in children and adolescents in their attainment of peak bone mass. Since bone adapts to the loads applied to it, increased mechanical loading leads to an increase in bone density. In analyzing 6 years of data investigating the influence of physical activity on bone mineral accrual during the adolescent years, researchers at the University of Saskatchewan in Canada found that pubertal boys and girls who exercised accrued $10-20 \%$ greater bone mass over a 2-year period than their sedentary counterparts. [33]. Moreover, findings from a 15-year longitudinal study tracking Dutch children from 13 to 28 years of age revealed that regular weight-bearing exercise had greater influence on peak bone mass than did dietary calcium intake [34]. Even premature, very-low-birth-weight infants have been found to benefit from a daily physical therapy program aimed at increasing bone mineralization and growth [35].

\section{Adulthood}

During the third decade of life, bones are no longer growing in length, but some sites demonstrate a small increment in bone mass. Reviews abound in the large body of literature supporting the benefits of higher levels of calcium and vitamin D supplementation for the bone health of virtually all adults [2]. One topic of importance of great recent controversy is the choice of calcium supplement to recommend for healthy adults. This is a matter of considerable economic and competitive interest among manufacturers.

In general, the bioavailability of calcium does not greatly differ among calcium sources. It has been shown in some studies [36], but not confirmed in others [37], that some forms of calcium, such as calcium citrate, are more bioavailable than others, such as calcium carbonate. It is not certain whether this difference is related to the solubility of the provided mineral, intrinsic aspects of the cal- 
cium salts, dissolution in the stomach and intestine, or the interrelationships between these supplements and other dietary components. Claims that some sources of calcium, such as 'coral calcium' are very rapidly absorbed or are $100 \%$ bioavailable should be rejected as being without evidence and contrary to known physiology.

Therefore, in the absence of compelling data to the contrary, it is reasonable to recommend that most consumers purchase the least expensive form of calcium, usually calcium carbonate, provided in soluble form by a reputable manufacturer [37]. It is highly advisable to recommend only calcium supplements that are provided with up to $400 \mathrm{IU}$ vitamin D. It is reasonable to consider for many people provision of calcium in combination with other minerals such as magnesium and zinc. This may not be necessary for those with a diet that is rich in these minerals. In special cases, such as those with known gastric disorders and in very small children, the use of calcium forms other than calcium carbonate may be appropriate.

Further research is needed to justify the widespread use of more expensive calcium salts. It is important that this research be conducted using the most accurate research methods, such as dual-tracer isotopes, rather than indirect measures, such as urinary changes in calcium concentration after a one-time dosing. Even more preferable would be controlled, blinded, long-term comparisons of bone mineral density after use of different calcium sources.

\section{Pregnancy and Lactation}

At birth, the newborn infant skeleton contains approximately $30 \mathrm{~g}$ of calcium. Most of this $30 \mathrm{~g}$ is derived from increased dietary calcium absorption during pregnancy in healthy adult women [38]. A period of 6 months of exclusive breast-feeding would lead to the secretion of an additional $45 \mathrm{~g}$ of calcium by the mother. Although some of this is provided by decreased urinary calcium excretion during lactation, there is extensive evidence of a loss of maternal bone mass during lactation [39, 40]. In most women, complete remineralization occurs after weaning; lactation is not generally associated with persistent gain or loss of bone mass or changes in overall risk of osteoporosis [41]. Surprisingly, studies indicate that calcium supplementation during lactation does not significantly alter bone loss or enhance bone mass recovery after weaning $[42,43]$.
The effects of pregnancy and lactation on the skeleton of young adolescents are less certain. There may be competition between mother and baby for absorbed calcium, with a loss of maternal peak bone mass. No specific data indicate any direct short- or long-term effects of lactation on adolescents; and especially for those more than 2-3 years postmenarche, it is unlikely to be a serious impediment to bone mineralization [2]. Therefore, it is likely that the considerable benefits of breast-feeding for infants and mothers greatly outweigh any demonstrated risk to adolescents. Although calcium supplementation has never been evaluated in a controlled fashion in pregnant adolescents, it should be noted that the recommended calcium intake level for teenagers of $1,300 \mathrm{mg} /$ day is substantially above typical dietary intake levels.

Women who are nursing more than one child, or women with closely spaced pregnancies, may be at increased risk for bone loss during lactation. It is noteworthy that some lactating women can have very high levels of milk output that completely support the milk needs of twins or triplets. Daily human milk volumes of 1-2 1 or more are possible. It is likely that the secretion into milk, for example, of $500 \mathrm{mg} /$ day of calcium, would lead to greater loss of maternal bone mass than the $250 \mathrm{mg} /$ day associated with nursing one child. However, there are no trials of calcium supplementation in women who are providing milk for more than one infant, nor are there specific data indicating a short- or long-term risk to maternal bones from full breast-feeding of twins or triplets. 


\section{References}

1 Matkovic V, Heaney RP: Calcium balance during human growth: Evidence for threshold behavior. Am J Clin Nutr 1992;55:992-996.

2 Institute of Medicine Food and Nutrition Board's Standing Committee on the Scientific Evaluation of Dietary Intervals. Calcium; in: Dietary Reference Intervals for Calcium, Phosphorus, Magnesium, Vitamin D and Fluoride. Washington, DC, National Academy Press, 1997, pp 71-146.

3 Committee on Nutrition, American Academy of Pediatrics: Calcium requirements of infants, children, and adolescents. Pediatrics 1999;104: 1152-1157.

4 Fomon SJ, Nelson SE: Calcium, phosphorous, magnesium, and sulfur; in Fomon SJ (ed): Nutrition of Normal Infants. St Louis, MO, Mosby Yearbook, 1993, pp 192-218.

5 Abrams SA, Wen J, Stuff JE: Absorption of calcium, zinc and iron from breast milk by 5 - to 7-month-old infants. Pediatr Res 1997;41:384390.

6 Abrams SA, Schanler RJ, Yergey AL, Vieira NE, Bronner F: Compartmental analysis of calcium metabolism in very low birth weight infants. Pediatr Res 1994;36:424-428.

7 Heaney RP, Recker RR, Stegman MR, Moy AJ: Calcium absorption in women: Relationships to calcium intake, estrogen status, and age. J Bone Miner Res 1989;4:469-475.

8 Jackman LA, Millane SS, Martin BR, Wood $\mathrm{OB}$, McCabe GP, Peacock M, Weaver CM: Calcium retention in relation to calcium intake and postmenarcheal age in adolescent females. Am J Clin Nutr 1997;66:327-333.

9 Bronner F, Abrams SA: Development and regulation of calcium metabolism in healthy girls. J Nutr 1998;128:1474-1480.

10 Abrams SA, O'Brien KO, Liang LK, Stuff JE: Differences in calcium absorption and kinetics between black and white girls age 5-16 years. J Bone Miner Res 1995;10:829-833.

11 Abrams SA, Copeland KC, Gunn SK, Gundberg CM, Klein KO, Ellis KJ: Calcium absorption, bone accretion and kinetics increase during early pubertal development in girls. J Clin Endocrinol Metab 2000;85:1805-1808.

12 Abrams SA, Esteban NV, Vieira NE, Sidbury JB, Specker BL, Yergey AL: Developmental changes in calcium kinetics in children assessed using stable isotopes. J Bone Miner Res 1992;7 287-293.

13 Martin AD, Bailey DA, McKay HA, Whiting S: Bone mineral and calcium accretion during puberty. Am J Clin Nutr 1997;66:611-615.

14 Ellis KJ, Abrams SA, Wong WW: Body composition in a young multiethnic female population. Am J Clin Nutr 1997;65:724-731.

15 Dawson-Hughes B, Harris SS, Finneran S, Rasmussen HM: Calcium absorption responses to calcitriol in black and white premenopausal women. J Clin Endocrinol Metab 1995;80 3068-3072.
16 Abrams SA, Copeland KC, Gunn SK, Stuff JE, Clark LL, Ellis KJ: Calcium absorption and kinetics are similar in 7- and 8-year-old Mexican-American and Caucasian girls despite hormonal differences. J Nutr 1999;129:666-671.

17 Lee WT, Cheng JC, Jiang J, Hu P, Hu X, Roberts DC: Calcium absorption measured by stable calcium isotopes $\left({ }^{42} \mathrm{Ca} \mathrm{\&}{ }^{44} \mathrm{Ca}\right)$ among Northern Chinese adolescents with low vitamin D status. J Orthop Surg (Hong Kong) 2002;10:61-66.

18 Schanler RJ: The use of human milk for premature infants. Pediatr Clin North Am 2001;48: 207-219.

19 Committee on Nutrition, American Academy of Pediatrics: Breastfeeding and the use of human milk. Pediatrics 1997;100:1035-1039.

20 Abrams SA: Nutritional rickets: an old disease returns. Nutr Rev 2002;60:111-115.

21 Pettifor JM: Rickets. Calcif Tissue Int 2002;70: 398-399.

22 Johnston CC Jr, Miller JZ, Slemenda CW, Reister TK, Hui S, Christian JC, Peacock M: Calcium supplementation and increases in bone mineral density in children. N Engl J Med 1992;327:82-87.

23 Slemenda CW, Peacock M, Hui S, Zhou L, Johnston CC: Reduced rates of skeletal remodeling are associated with increased bone mineral density during the development of peak skeletal mass. J Bone Miner Res 1997;12:676682.

24 Bonjour JP, Chevalley T, Ammann P, Slosman $\mathrm{D}$, Rizzoli R: Gain in bone mineral mass in prepubertal girls 3.5 years after discontinuation of calcium supplementation: a follow-up study. Lancet 2001;358:1208-1212.

25 Abrams SA, O'Brien KO, Stuff JE: Changes in calcium kinetics associated with menarche. J Clin Endocrinol Metab 1996;81:2017-2020.

26 Teegarden D, Proulx WR, Martin BR, Zhao J, McCabe GP, Lyle RM, Peacock M, Slemenda C, Johnston CC, Weaver CM: Peak bone mass in young women. J Bone Miner Res 1995;10: $711-715$.

27 Matkovic V, Jelic T, Wardlaw GM, Ilich JZ, Goel PK, Wright JK, Andon MB, Smith KT, Heaney RP: Timing of peak bone mass in Caucasian females and its implication for the prevention of osteoporosis. J Clin Invest 1994;93: 799-808.

28 Heaney RP, Abrams SA, Dawson-Hughes B, Looker A, Marcus R, Matkovic V, Weaver C: Peak bone mass. Osteoporos Int 2000;11:9851009.

29 Ames SK, Ellis KJ, Gunn SK, Copeland KC, Abrams SA: Vitamin D receptor gene Fok1 polymorphism predicts calcium absorption and bone mineral density in children. J Bone Miner Res 1999;14:740-746.
30 Goulding A, Cannan R, Williams SM, Gold EJ Taylor RW, Lewis-Barned NJ: Bone minera density in girls with forearm fractures. J Bone Miner Res 1998;13:143-148.

31 Wyshak G, Frisch RE: Carbonated beverages, dietary calcium, the dietary calcium/phosphorus ratio, and bone fractures in girls and boys. $\mathrm{J}$ Adolesc Health 1994; 15:210-215.

32 Wyshak G: Teenaged girls, carbonated beverage consumption, and bone fractures. Arch Pediatr Adolesc Med 2000;154:610-613.

33 Bailey DA, McKay HA, Mirwald RL, Crocker PRE, Faulkner RA: A six-year longitudinal study of the relationship of physical activity to bone mineral accrual in growing children: The University of Saskatchewan Bone Mineral Accrual Study. J Bone Miner Res 1999;14:16721679.

34 Welten DC, Kemper HCG, Post GB, Van Mechelen W, Twisk J, Lips P, Teule GJ: Weightbearing activity during youth is a more important factor for peak bone mass than calcium intake. J Bone Miner Res 1994;9:1089-1096.

35 Moyer-Mileur LJ, Brunstetter V, McNaught TP, Gill G, Chan GM: Daily physical activity program increases bone mineralization and growth in preterm very low birth weight infants. Pediatrics 2000;106:1088-1092.

36 Sakhaee K, Bhuket T, Adams-Huet B, Rao DS: Meta-analysis of calcium bioavailability: A comparison of calcium citrate with calcium carbonate. Am J Ther 1999;6:313-321.

37 Heaney RP, Dowell SD, Bierman J, Hale CA, Bendich A: Absorbability and cost effectiveness in calcium supplementation. J Am Coll Nutr 2001;20:239-246.

38 Heaney RP, Skillman TG: Calcium metabolism in normal human pregnancy. J Clin Endocrinol Metab 1971;33:661-670.

39 Ritchie LD, Fung EB, Halloran BP, Turnland JR, Van Loan MD, Cann DE: A longitudinal study of calcium homeostasis during human pregnancy and lactation and after resumption of menses. Am J Clin Nutr 1998;67:693-701.

40 Cross NA, Hillman LS, Allen SH, Krause GF Changes in bone mineral density and markers of bone remodeling during lactation and postweaning in women consuming high amounts of calcium. J Bone Miner Res 1995;10:13121320 .

41 Hopkinson JM, Butte NF, Ellis K, Smith EO: Lactation delays postpartum bone mineral accretion and temporarily alters its regional distribution in women. J Nutr 2000;30:777-783.

42 Kalkwarf HJ, Specker BL, Bianchi DC, Ranz J, Ho M: The effect of calcium supplements on bone density during lactation and after weaning. N Engl J Med 1997;337:523-528.

43 Allen LH: Women's dietary calcium requirements are not increased by pregnancy or lactation. Am J Clin Nutr 1998;67:591-592. 